\title{
ANALISIS STRATEGI RANTAI PASOK INDUSTRI PENGOLAHAN TAHU DI KELURAHAN PANARUNG KECAMATAN PAHANDUT KOTA PALANGKA RAYA (Studi Kasus: Industri Pengolahan Tahu Citra Puspita)
}

\author{
${ }^{1}$ Chintya Prisca Pricilla, ${ }^{2}$ Trisna Anggreini, ${ }^{3}$ Yuni Erlina
}

\author{
${ }^{1}$ Alumnus Program Studi Agribisnis Fakultas Pertanian Universitas Palangka Raya \\ ${ }^{2,}{ }^{3}$ Staf Pengajar Program Studi Agribisnis Fakultas Pertanian Univesitas Palangka Raya
}

Email: chintya.prisca.p@gmail.com

\begin{abstract}
ABSTRAK
Sektor industri merupakan salah satu tulang punggung perekonomian nasional dan sumber penghidupan sebagian besar rakyat Indonesia. Salah satu industri pengolahan yang cukup potensial adalah industri pengolahan kedelai, misalnya pengolahan kedelai menjadi tahu. Konsep rantai pasok menekankan pada pola yang terintegrasi dalam proses aliran produksi mulai dari bahan mentah yaitu kedelai sampai produk olahan berupa tahu tiba di tangan konsumen akhir. Tujuan penelitian ini adalah mengetahui pola aliran rantai pasok pada industri pengolahan tahu Citra Puspita di Kelurahan Panarung, Kecamatan Pahandut, Kota Palangka Raya, mengetahui pihak yang terlibat dalam rantai pasok pada industri pengolahan tahu Citra Puspita di Kelurahan Panarung, Kecamatan Pahandut, Kota Palangka Raya, dan menganalisis strategi rantai pasok pada industri pengolahan tahu Citra Puspita di Kelurahan Panarung, Kecamatan Pahandut, Kota Palangka Raya. Analisis data yang digunakan dalam penelitian ini mengunakan analisis rantai pasok, analisis SWOT, matriks IFAS, matriks EFAS, dan matriks SWOT. Hasil penelitian menunjukkan bahwa pola aliran rantai pasok pada industri pengolahan tahu Citra Puspita terdiri dari 3 pola aliran produk, kas, dan informasi yaitu Importir, Distributor, terakhir ke Industri Pengolahan Tahu, Pedagang Besar atau Pedagang Pengecer Tahu, terakhir ke Konsumen Akhir, Pihakpihak pada rantai pasok industri pengolahan tahu Citra Puspita yaitu importir kedelai yaitu PT FKS Multi Agro Tbk, distributor kedelai yaitu Bapak Heri dari Kota Banjarmasin, industri pengolahan tahu Citra Puspita, pedagang besar tahu, pedagang pengecer tahu, dan konsumen akhir serta penyedia bahan pendukung lain, serta berdasarkan analisis SWOT posisi industri pengolahan tahu Citra Puspita berada pada kuadran I yang berarti berada pada situasi yang menguntungkan dengan posisi strategi SO.
\end{abstract}

Kata Kunci : Industri Pengolahan, Tahu, Rantai Pasok, Strategi 


\begin{abstract}
The industrial sector is one of the backbones of the national economic and also the source of livelihood for the most of Indonesians. One of the potential processing industries is the soybean processing industrial, for example processing soybeans into tofu. The supply chain concept emphasizes an integrated pattern in the production flow process, from raw materials which is soybeans, to processed products in the form of tofu, arriving to the hands of the final consumer. The purpose of this study was to determine the supply chain flow pattern in the tofu processing industry "Citra Puspita" in Panarung Village, Pahandut District, Palangka Raya, to determine the parties involved in the supply chain in the tofu processing industry "Citra Puspita" in Panarung Village, Pahandut District, Palangka Raya, and analyzing the supply chain strategy in the tofu processing industry "Citra Puspita" in Panarung Village, Pahandut District, Palangka Raya. Analysis of the data used in this study uses supply chain analysis, SWOT analysis, IFAS matrix, EFAS matrix, and SWOT matrix. The results showed that the supply chain flow pattern in the Citra Puspita tofu processing industry consisted of 3 patterns of product, cash, and information flow, which is importers, distributors, the last to the Tofu Processing Industry, Wholesaler or Tofu Retailer, the last to the final consumer, The parties in the supply chain of tofu processing industry "Citra Puspita" are soybeans importers namelu PT FKS Multi Agro Tbk, soybean distributor namely Mr. Heri, tofu processing industry "Citra Puspita", wholesaler or tofu retailer, final consumers, and material providers others supporters, and based on a SWOT analysis, the position of the tofu processing industry "Citra Puspita" is in quadrant I which means that it is in a favorable situation with the SO strategy position.
\end{abstract}

\title{
Keywords $\quad$ : Processing Industry, Tofu, Supply Chain, Strategy
}

\section{PENDAHULUAN}

Sektor industri merupakan salah satu tulang punggung perekonomian nasional dan sumber penghidupan sebagian besar rakyat Indonesia. Pada Profil Industri dan Kecil Provinsi Kalimantan Tengah Tahun 2018, menurut Badan Pusat Statistik (2019), secara umum pembangunan sektor industri pengolahan nasional mencanangkan pembangunan industri yang berdaya saing dengan struktur industri yang kuat berbasis sumber daya alam, inovasi dan teknologi serta berkeadilan. Pembangunan industri pengolahan diharapkan menghasilkan karakteristik yang salah satunya adalah adanya sinergitas yang kuat antara industri kecil, menengah, dan besar yang menjalankan perannya sebagai sebuah rantai pasok (supply chain). Sesuai arahan Rencana Pembangunan Jangka Panjang Nasional (RPJPN) 2005-2025, sasaran pembangunan jangka menengah 2020-2024 adalah mewujudkan masyarakat Indonesia yang mandiri, maju, adil, dan makmur melalui percepatan pembangunan di berbagai bidang dengan menekankan terbangunnya struktur perekonomian yang kokoh berlandaskan keunggulan kompetitif di berbagai wilayah yang didukung oleh sumber daya manusia yang berkualitas dan berdaya saing. RPJMN 2020-2024 telah mengarusutamakan

Sustainable Development Goals (SDGs). Target-target dari 17 Tujuan Pembangunan Berkelanjutan 
(SDGs) beserta indikatornya telah menjadi bagian yang tidak terpisahkan dalam 7 agenda pembangunan Indonesia ke depan (PPRI No 18, 2020).

Visi Misi Presiden 2020-2024 disusun berdasarkan arahan RPJPN 2005-2025. Adapun isi visi tersebut adalah "Terwujudnya Indonesia Maju yang Berdaulat, Mandiri, dan Berkepribadian Berlandaskan Gotong Royong". Visi tersebut diwujudkan melalui 9 misi yang dikenal sebagai Nawacita Kedua. Salah satu misi dalam Nawacita Kedua yaitu Struktur Ekonomi yang Produktif, Mandiri dan Berdaya Saing. Pemerintah dalam mencapai visi misi di sektor industri pengolahan menetapkan sasaran-sasaran yang salah satunya adalah pengembangan sentra industri kecil. Hal ini dilakukan untuk meningkatkan kontribusi khususnya industri kecil dalam perekonomian nasional. Dengan harapan industri pengolahan berkontribusi dalam PDB, yang mana di tahun 2018 sebesar 19,9\% meningkat di tahun 2024 menjadi sebesar 21,0\% (PPRI No 18, 2020).

Menurut Widiantoro pengembangan industri pengolahan pangan di Indonesia didukung oleh sumberdaya alam pertanian, baik nabati maupun hewani yang mampu menghasilkan berbagai produk olahan yang dapat dibuat dan dikembangkan dari sumber daya alam lokal. Salah satu industri pengolahan yang cukup potensial adalah industri pengolahan kedelai, misalnya pengolahan kedelai menjadi tahu. Berdasarkan data dari Dinas Perdagangan dan Perindustrian Provinsi Kalimantan Tengah tahun 2020, salah satu industri pengolahan kedelai menjadi tahu di Kota Palangka Raya yaitu industri pengolahan tahu Citra Puspita milik Bapak Joko di Jalan Meranti, Kelurahan Panarung, Kecamatan Pahandut. Pada industri pengolahan tahu Citra Puspita, bahan baku utama yaitu kedelai hanya berasal dari satu sumber atau termasuk dalam strategi few supplier (sedikit pemasok). Peneliti memilih industri pengolahan tahu Citra Puspita di Kelurahan Panarung karena industri ini memiliki beberapa keunggulan. Pertama, industri pengolahan tahu Citra Puspita sudah memiliki Surat Izin Usaha
Perdagangan (SIUP) Kecil yang dikeluarkan oleh Kantor Pelayanan Perizinan Terpadu dengan nomor: 503.3/152/SIUP-PK/II/2011. Kedua, karena industri pengolahan tahu Citra Puspita ini sudah berdiri sejak tahun 2002 dan masih bertahan sampai sekarang walaupun di kondisi Pandemi COVID-19 sekarang ini. Berdasarkan hasil observasi awal, pada saat kondisi Pandemi COVID-19 banyak industri pengolahan kedelai baik menjadi tahu atau tempe gulung tikar karena tidak mampu bertahan. Ketiga, karena berada di tengah Kota Palangka Raya sehingga untuk menjangkau mulai dari bahan baku hingga ke konsumen akhir masih dapat terjangkau dengan mudah.

Rantai pasok industri pengolahan tahu dapat lebih berkembang jika strategi pada aliran bahan baku, aliran informasi, dan aliran keuangan berjalan dengan lancar serta adanya keterbukaan dari para pelaku rantai pasok industri pengolahan terhadap informasi yang diterimanya. Berhasil atau tidaknya rantai pasok dapat dilihat dari berjalan dengan lancar atau tidaknya rantai pasok tersebut.

Penelitian ini bertujuan untuk 1) Mengetahui pola aliran rantai pasok pada industri pengolahan tahu Citra Puspita di Kelurahan Panarung, Kecamatan Pahandut, Kota Palangka Raya; 2) Mengetahui pihak yang terlibat dalam rantai pasok pada industri pengolahan tahu Citra Puspita di Kelurahan Panarung, Kecamatan Pahandut, Kota Palangka Raya; 3) Menganalisis strategi rantai pasok pada industri pengolahan tahu Citra Puspita di Kelurahan Panarung, Kecamatan Pahandut, Kota Palangka Raya.

\section{METODE PENELITIAN}

\section{Lokasi dan Waktu Penelitian}

Lokasi penelitian ini dilakukan di industri pengolahan tahu yaitu Citra Puspita di Kelurahan Panarung Kecamatan Pahandut Kota Palangka Raya. Lokasi penelitian ditentukan secara pusposive sampling berdasarkan pertimbangan karena pada industri pengolahan tahu Citra Puspita ini sesuai dengan kriteria yaitu industri kecil yaitu dengan 5-19 tenaga 
kerja. Waktu penelitian dilaksanakan dari bulan Januari-Maret 2021 meliputi penyusunan usulan penelitian, pengumpulan data di lapangan, dan analisis data hingga penulisan hasil penelitian.

\section{Penentuan Informan}

Informan kunci dalam penelitian ini adalah pemilik industri pembuatan tahu yaitu Bapak Joko. Informan kunci pada industri pengolahan tahu ditentukan secara purposive sampling yang dipilih berdasarkan pertimbangan skala produksi, banyaknya tenaga kerja, dan kesesuaian dengan data yang diperlukan dalam penelitian. Pengumpulan data informan lain yang terkait dengan rantai pasok industri pengolahan tahu meliputi pemasok bahan baku, pemasok bahan pendukung, pedagang besar tahu, dan pedagang pengecer tahu. Teknik pengumpulan data informan lain menggunakan cara snowball sampling dengan pertimbangan karena tidak ada informasi yang pasti mengenai jumlah pihak yang terlibat dalam rantai pasok industri pengolahan tahu ini.

\section{Sumber Data dan Pengumpulan Data}

Metode pengambilan data untuk sumber data dalam penelitian ini adalah dengan melakukan wawancara, yang dimaksud dengan wawancara adalah proses memperoleh keterangan langsung dengan cara tanya jawab, sambil bertatap muka antara peneliti dan responden dengan menggunakan daftar pertanyaan yang telah dipersiapkan sebelumnya (Nazir, 2009). Pengumpulan data juga dilakukan dengan studi dokumen, data yang dikumpulkan berupa data sekunder yang diperlukan untuk melengkapi data yang diperoleh. Data sekunder dapat diperoleh dari Badan Pusat Statistik Provinsi Kalimatan Tengah, Dinas Perindustrian dan Perdagangan Provinsi Kalimantan Tengah, maupun dokumen terkait. Pengumpulan data juga dilakukan menggunakan observasi lapangan. Kegiatan ini bertujuan untuk mengetahui kondisi sesungguhnya di lapangan serta memastikan pernyataan yang diberikan oleh informan.

\section{Pengolahan dan Analisis Data}

Penelitian ini menggunakan metode analisis kualitatif, analisis deskriptif, serta analisis SWOT. Analisis kualitatif bertujuan menguraikan gambaran keadaan lokasi penelitian dan mendeskripsikan rantai pasokan dari produsen hingga ke konsumen akhir. Analisis data secara deskriptif dilakukan untuk mengetahui aliran bahan baku, aliran informasi, dan aliran kas dari rantai pasok pada industri pengolahan tahu. Dengan melakukan wawancara, maka akan tergambarkan rantai pasok pada industri rumah tangga pengolahan tahu Citra Puspita

Untuk mengetahui pola aliran rantai pasok pada industri pengolahan tahu Citra Puspita, diselesaikan menggunakan analisis kualitatif dan analisis deskriptif. Analisis secara kualitatif dan deskriptif dilakukan untuk mengetahui aliran bahan baku, aliran informasi, dan aliran kas dengan proses wawancara dengan informan sehingga dapat digambarkan dalam bentuk skema aliran. Analisis kualitatif bertujuan untuk menjelaskan fenomena dengan sedalamdalamnya melalui pengumpulan data sedalam-dalamnya.

Untuk mengetahui pihak yang terlibat pada industri pengolahan tahu Citra Puspita, diselesaikan menggunakan analisis deskriptif dan kualitatif dengan metode snowball sampling. Tujuan yang ingin dicapai dari pengunaan analisis secara deskriptif yaitu mengupayakan penelitian dengan cara menggambarkan secara sistematis, faktual, dan akurat dari suatu fakta pada peristiwa yang terjadi mengenai aliran bahan baku, aliran kas, dan aliran informasi pada setiap pelaku rantai pasok industri pengolahan tahu Citra Puspita. Dengan metode snowball sampling, maka semakin dalam dan detail data yang didapatkan, sehingga semakin baik kualitas dari penelitian ini.

Untuk menganalisis strategi rantai pasok pada industri pengolahan tahu Citra Puspita, diselesaikan menggunakan metode analisis SWOT. Analisis ini menempatkan situasi dan juga kondisi sebagai sebagai faktor masukan, lalu kemudian 
dikelompokkan menurut kontribusinya masing-masing. Analisis internal dan eksternal dari industri pengolahan tahu Citra Puspita kemudian dimasukkan kedalam Matrik SWOT.

\section{HASIL DAN PEMBAHASAN}

\section{Pola Aliran Rantai Pasok pada Industri Pengolahan Tahu Citra Puspita}

Pola aliran rantai pasok pada industri pengolahan tahu Citra Puspita di Kelurahan Panarung, Kecamatan Pahandut, Kota Palangka Raya dianalisis berdasarkan anggota yang membentuk rantai pasok dan peran dari setiap anggota. Anggota rantai pasok yang dimaksud adalah pihak-pihak yang terlibat dan memiliki peran dalam rantai pasok industri pengolahan tahu ini baik secara langsung maupun tidak langsung. Berdasarkan analisis tersebut, pola aliran rantai pasok pada industri pengolahan tahu Citra Puspita dapat di Kelurahan Panarung, Kecamatan Pahandut, Kota Palangka Raya dapat dilihat pada Gambar 1.

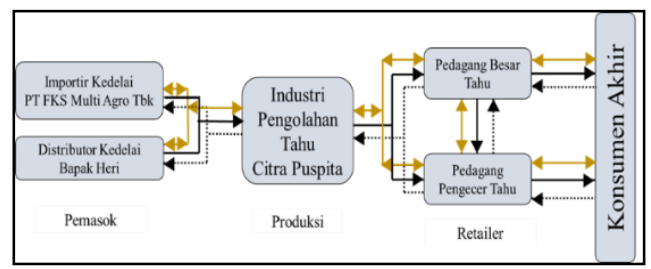

Gambar 1. Pola Aliran Rantai Pasok Industri Pengolahan Tahu Citra Puspita (Sumber: Data Primer yang Diolah, 2021).

Keterangan :

$$
\begin{aligned}
\longrightarrow & =\text { Aliran Produk } \\
\longleftrightarrow & =\text { Aliran Informasi } \\
\hookrightarrow \cdots \cdots . . . . & =\text { Aliran Kas }
\end{aligned}
$$

\section{Pihak-Pihak yang Terlibat dalam Rantai Pasok pada Industri Pengolahan Tahu Citra Puspita}

Rantai pasok terdiri dari beberapa unsur dan pihak yang terlibat baik secara langsung ataupun tidak langsung. Anggota rantai pasok dalam hal ini adalah lembaga atau pihak yang terlibat dalam aliran produk, aliran kas, dan aliran informasi mulai dari petani kedelai hingga konsumen akhir. Keseluruhan pelaku rantai pasok tersebut melakukan kegiatan yang saling berhubungan dengan kegiatan operasional sehingga dapat menghasilkan produk tahu sampai ke tangan konsumen akhir.

Importir kedelai adalah PT FKS Multi Agro Tbk yang merupakan importir kedelai terbesar yang hampir $45 \%$ memenuhi kuota impor kedelai di Indonesia.

Distributor kedelai adalah Bapak Heri berasal dari Kota Banjamasin. Distributor adalah pedagang yang membeli kedelai dari importir kedelai yang selanjutnya didistribusikan ke pedagang pengecer atau langsung ke industri pengolahan kedelai di berbagai tempat (lintas provinsi dan kabupaten/kota).

Industri pengolahan tahu adalah pihak yang melakukan permintaan komponen kepada pemasok bahan baku untuk kemudian di produksi. Jika kedelai yang telah didapatkan dari distributor, proses selanjutnya adalah mengolah kedelai untuk menghasilkan tahu yang kemudian dijual ke pedagang besar, pedagang pengecer dan atau langsung kepada konsmen akhir.

Pedagang besar adalah pedagang yang membeli tahu dari produsen kemudian di jual ke pedagang pengecer luar atau dalam kota. Berdasarkan hasil wawancara, pedagang besar dapat menjual tahu hingga ke Kuala Kurun, Gunung Mas, Muara Teweh, dan lain-lain.

Pedagang pengecer adalah pedagang yang menjual tahu secara langsung kepada konsumen akhir. Berdasarkan hasil wawancara bahwa pedagang pengecer pada umumnya adalah pedagang sayur.

Konsumen merupakan rantai pasok terakhir dari sistem rantai pasok pada industri pengolahan tahu Citra Puspita. Produk tahu berakhir untuk dikonsumsi sebagai makanan yang diolah kembali. Konsumen akhir pada rantai pasok ini sebagian besar adalah ibu rumah tangga yang mengkonsumsi untuk keluarga sendiri tanpa di jual kembali.

Pada rantai pasok industri pengolahan tahu Citra Puspita terdapat bahan pendukung lainnya seperti penyedia kayu bakar, cuka atau biang tahu, plastik untuk membungkus, minyak goreng, dan beberapa bahan pendukung lainnya 


\section{Analisis Strategi Rantai Pasok pada Industri Pengolahan Tahu Citra Puspita} Analisis Faktor Internal pada Rantai Pasok Aliran Produk

Kualitas merupakan sesuatu hal yang sangat penting bagi pordusen dalam menghasilkan suatu produk. Kualitas tahu yang baik sangat tergantung dari beberapa hal diantaranya, kualitas kedelai, kebersihan saat proses produksi, campuran yang digunakan hingga cara pengemasan. Biasanya kualitas kedelai untuk industri pengolahan tahu mempunyai persyaratan yang ketat seperti bebas dari sisa tanaman atau bersih baik dari potongan ranting, kulit polong, batu atau kotoran lain serta biji kedelai tidak luka atau bebas terserang hama, tidak retak atau pecah, dan tidak keriput. Kedelai yang digunakan oleh industri pengolahan tahu Citra Puspita adalah kedelai impor dari Amerika Serikat. Kedelai di impor oleh PT FKS Multi Agro Tbk yang kemudian di distribusikan kembali oleh distributor yang berasal dari Kota Banjarmasin. Dalam proses produksinya keadaan di lokasi industri pengolahan tahu Citra Puspita tergolong bersih dan rapi seperti industri pengolahan tahu pada umumnya. Produk tahu dari industri ini tidak menggunakan bahan yang berbahan contohnya tidak menggunakan zat yang mengandung senyawa kimia berbahaya ataupun pengawet sehingga produk tahu hanya mampu bertahan 1-2 hari. Tahu yang diproduksi ada beberapa varian yaitu, tahu putih, tahu goreng, dan tahu sumedang.

\section{Aliran Kas}

Kas atau keuangan adalah salah satu variabel yang perlu diperhatikan oleh produsen karena harga akan langsung mempengaruhi besarnya volume penjualan dan laba yang akan diperoleh. Industri tahu Citra Puspita menentukan harga berdasarkan ukuran produk tahu yang dijual. Ada 3 ukuran produk tahu di industri ini yaitu $5 \times 5 \mathrm{~cm}, 6 \times 6 \mathrm{~cm}$, dan $7 \times 7 \mathrm{~cm}$. Harga tahu berkisar antara Rp. 400 sampai Rp. 1.000 tergantung varian produk tahu. Meskipun harga bahan baku utama yaitu kedelai per bulan Maret 2021 mencapai Rp.
$11.000 / \mathrm{kg}$, harga produk tahu yang dijual tidak berubah. Dalam setiap 2 minggu, produsen harus mengeluarkan uang untuk membeli bahan baku kedelai sebesar Rp. 38.500.000. Produsen memilih untuk menyiasati dengan mengurangi produksi bukan menaikkan harga produk tahu agar tetap terjangkau oleh konsumen. Akibatnya, pendapatan juga akan menurun. Modal usaha yang terbatas juga akan mempengaruhi pengembangan industri untuk menjadi lebih besar lagi.

\section{Aliran Informasi}

Informasi pasar yang termasuk didalamnya permintaan dan penawaran juga penting. Informasi juga diperlukan untuk mengenalkan dan menjual produk yang telah dibuat oleh produsen kepada masyarakat luas. Lokasi industri yang strategis dengan pasar juga mempermudah distribusi produk tahu. Dalam hal perluasan informasi mengenai produk tahu yang diproduksi, produsen memiliki beberapa cara misalnya memilih mempromosikan produknya dengan komunikasi bertatap muka secara langsung antara calon konsumen dengan produsen. Kemudian, ada juga beberapa konsumen yang memang sudah mengetahui informasi tentang produk tahu dari industri Citra Puspita, ada yang langsung membeli di lokasi industri pengolahan atau dapat memesan via aplikasi WhatsApp dengan produsen. Adanya pedagang besar dan pedagang pengecer tahu membuat perluasan informasi mengenai produk tahu yang diproduksi. Perluasan informasi dengan cara seperti ini dianggap lebih efektif dan tidak memerlukan banyak biaya.

Analisis Faktor Eksternal pada Rantai Pasok

\section{Aliran Produk}

Pada bagian produk, salah satu yang terpenting adalah kontinuitas bahan baku utama yaitu kedelai. Terjaminnya kelangsungan bahan baku sangat berpengaruh bagi produksi di industri pengolahan tahu Citra Puspita. Terjaminnya bahan baku akan sangat berpengaruh bagi persaingan kualitas maupun kuantitas antar 
pengrajin tahu. Namun, dengan adanya produk substitusi atau pengganti seperti tahu juga mempengaruhi penjualan produk tahu ke konsumen.

\begin{abstract}
Aliran Kas
Pada bagian kas atau keuangan, dengan harga yang terjangkau maka dapat pula menjangkau konsumen yang lebih banyak. Namun, fluktuasi harga bahan baku utama kedelai juga tidak dapat dihindari. Jika dari importir sudah mahal, maka bahan baku yang didistribusikan oleh distributor ke produsen juga akan mahal. Menurut hasil wawancara, harga kedelai per bulan Maret 2021 sudah mencapai Rp.11.000/ kg. Hal ini juga berpengaruh terhadap pendapatan, karena produsen produk tahu tidak dapat menaikkan harga jual karena kemungkinan konsumen enggan membelinya. Apabila bahan baku naik dan harga jual juga naik, maka dapat menyebabkan harga produk dari pesaing menjadi lebih murah sehingga bisa membuat penjualan menurun.
\end{abstract}

\section{Aliran Informasi}

Konsumen menginginkan makan makanan yang bergizi dan sehat namun murah, sehingga membeli produk tahu menjadi salah satu pilihan. Informasi yang beredar mengenai pentingnya memakan makanan bergizi dan sehat mempengaruhi keputusan konsumen dalam membeli produk tahu, terlebih dalam kondisi pandemi COVID-19 ini. Selain itu, masyarakat sudah banyak yang melek akan teknologi sehingga dapat dengan mudah memesan melalui aplikasi WhatsApp.

Identifikasi Faktor Internal pada Rantai Pasok Industri Pengolahan Tahu Citra Puspita

\section{Faktor Internal \\ No. Kekuatan}

1. Bahan baku utama yaitu kedelai berkualitas tinggi.

2. Harga produk tahu yang dijual terjangkau.

3. Produk tahu yang di produksi unggulan serta terjamin mutunya.

4. Lokasi industri yang strategis $\pm 2 \mathrm{~km}$ ke arah pasar tradisional, sehingga mempermudah distribusi produk tahu.

5. Memproduksi berbagai jenis tahu, yaitu tahu putih, tahu goreng, dan tahu sumedang.

6. Sudah memiliki informasi mengenai permintaan dan penjualan di pasar.

\section{Kelemahan}

1. Bahan baku kedelai di supply dari Kota Banjarmasin.

2. Produk tahu tidak dapat bertahan lama.

3. Modal usaha yang terbatas.

Sumber: Data Primer yang Diolah, 2021

Identifikasi Faktor Eksternal pada Rantai Pasok Industri Pengolahan Tahu Citra Puspita

\section{Faktor Eksternal}

No. Peluang

1. Kontinuitas bahan baku terjamin.

2. Pedagang pengecer membantu memperluas pemasaran produk.

3. Sudah banyak konsumen yang melek teknologi sehingga mempermudah pemasaran secara online (via WhatsApp)

4. Konsumen memilih makanan yang bergizi dan sehat namun murah.

\section{Ancaman}

1. Adanya persaingan kualitas dan kuantitas tahu antar industri tahu

2. Adanya fluktuasi harga bahan baku

3. Harga produk sama dari pesaing yang lebih murah

4. Produk substitusi yang beragam

Sumber: Data Primer yang Diolah, 2021

Pada perhitungan matriks IFAS menunjukkan total nilai skor faktor internal ialah sebesar 3,462. Hal ini mengindikasikan posisi internal industri pengolahan tahu Citra Puspita berada diatas rata-rata yaitu sebesar 2,5 dalam memanfaatkan kekuatan dan mengatasi kelemahan internalnya. Dengan demikian industri pengolahan tahu Citra Puspita berada pada posisi kuat secara internal. Pada perhitungan matriks EFAS menunjukkan total nilai skor faktor eksternal ialah sebesar 3,168. Hal ini mengindikasikan posisi eksternal industri pengolahan tahu Citra Puspita berada diatas rata-rata yaitu sebesar 2,5 dalam memanfaatkan peluang dan mengatasi ancaman eksternalnya. Dengan demikian 
industri pengolahan tahu Citra Puspita berada pada posisi kuat secara eksternal.

Berdasarkan hasil perhitungan dari nilai skor faktor internal diperoleh hasil pengurangan antara nilai total skor faktor kekuatan dan nilai total skor faktor kelemahan yaitu $2,571-0,891=1,68$ (positif, sebagai sumbu X). Hasil perhitungan dari nilai skor faktor eksternal diperoleh hasil pengurangan antara nilai total skor faktor peluang dan nilai total skor faktor ancaman yaitu 1,793 - 1,375 =0,418 (positif, sebagai sumbu Y). Sehingga posisi industri pengolahan tahu Citra Puspita berada pada kuadran I yang berarti berada pada situasi yang menguntungkan dengan posisi strategi SO. Strategi yang diterapkan daam kondisi ini yaitu mendukung kebijakan pertumbuhan agresif. Berikut gambar diagram SWOT yang dapat dilihat pada Gambar 2.

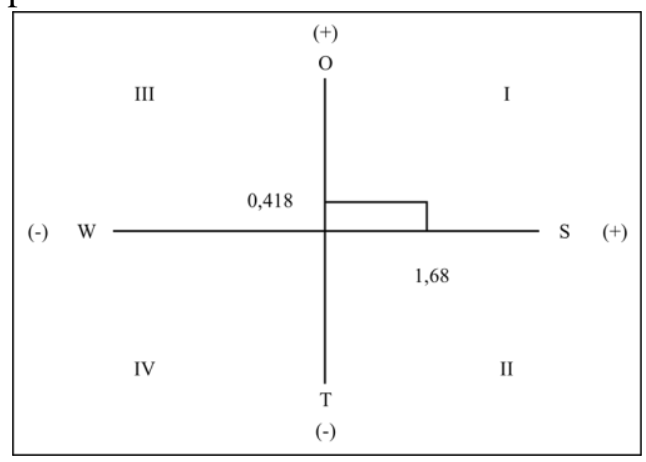

Gambar 2. Diagram SWOT Hasil Analisis pada Industri Pengolahan Tahu Citra Puspita (Sumber: Data Primer yang Diolah, 2021)

Hasil nilai total skor yang diperoleh dari matriks Internal Strategic Factors Analysis Summary (IFAS) sebesar 3,462 dan nilai skor matriks External Strategic Factors Analysis Summary (EFAS) sebesar 3,168. Dari hasil skor matriks tersebut, maka tahap yang dilakukan selanjutnya adalah menyusun hasil dari matriks IFAS dan EFAS menggunakan matriks InternalExternal (IE) yang berguna untuk mengetahui posisi untuk menentukan strategi pemasaran. Berikut tabel matriks IE untuk industri pengolahan tahu Citra Puspita.

\begin{tabular}{|cccccc|}
\hline & \multirow{2}{*}{ Matriks IE } & & \multicolumn{3}{c}{ Skor IFAS $(3,462)$} \\
\cline { 3 - 6 } & & & $3,0-4,0$ & $2,0-2,99$ & $1,0-1,99$ \\
\hline \multirow{2}{*}{ Skor EFAS } & $3,0-4,0$ & Tinggi & I & II & III \\
$(3,168)$ & $2,0-2,99$ & Sedang & IV & V & VI \\
& $1,0-1,99$ & Lemah & VII & VIII & IX \\
\hline
\end{tabular}

Sumber: Data Primer yang Diolah, 2021

Berdasarkan diatas dapat dilihat total skor matriks IFAS sebesar 3,462 dan total skor matriks EFAS sebesar 3,168 sehingga menunjukkan posisi bahwa industri pengolahan tahu Citra Puspita berada pada kuadran I yang berarti growth strategic atau industri pengolahan tersebut berada pada kondisi strategi pertumbuhan melalui strategi integrasi vertikal. Pertumbuhan melalui konsentrasi dapat dicapai melalui integrasi vertikal dengan cara backward integration (mengambil alih fungsi supplier) atau dengan cara forward integration (mengambil alih fungsi distributor). Agar dapat meningkatkan kekuatan bisnisnya atau posisi kompetitifnya, perusahaan ini harus melaksanakan upaya meminimalkan biaya dan operasi yang tidak efisien untuk mengontrol kualitas serta distribusi produk. Integrasi vertikal dapat dicapai baik melalui sumber daya internal maupun eksternal

\section{Hasil Analisis Strategi Rantai Pasok pada Industri Pengolahan Tahu Citra Puspita}

Matriks SWOT diketahui terdapat empat strategi diantaranya strategi S-O, strategi S-T, strategi W-O, dan strategi WT. Yang mana, strategi S-O merupakan strategi yang menggunakan kekuatan untuk memanfaatkan peluang dalam suatu perusahaan, strategi S-T merupakan strategi yang menggunakan kekuatan untuk mengatasi atau menghindari ancaman, strategi W-O merupakan strategi untuk mengatasi kelemahan dan memanfaatkan peluang dan strategi S-T merupakan strategi untuk meminimalisir kelemahan dan menghindari ancaman.

Berikut beberapa strategi yang dapat diterapkan untuk mengembangkan industri pengolahan tahu Citra Puspita.

\section{Strategi S-O}


1. Bahan baku utama yaitu kedelai berkualitas tinggi dan kontinuitas bahan baku terjamin untuk proses produksi setiap harinya.

2. Harga produk tahu yang di jual terjangkau dan produk tahu yang unggulan serta terjamin mutunya membuat pemasaran produk menjadi lebih luas, dibantu dengan adanya pedagang pengecer

3. Harga produk tahu yang di jual terjangkau dan produk tahu yang unggulan serta terjamin mutunya membuat pemasaran produk menjadi lebih luas dengan kemudahan pemasaran secara online.

4. Lokasi industri yang strategi mempermudah distribusi produk tahu sehingga mempermudah juga dalam pemasaran produk.

5. Konsumen memilih makanan yang bergizi dan sehat namun murah, seperti contohnya tahu dengan berbagai varian seperti tahu putih, tahu sumedang, dan tahu goreng yang dapat dipilih sesuai selera konsumen

6. Lokasi industri yang strategis mempermudah distribusi dan sudah memiliki informasi mengenai permintaan dan penjualan di pasar maka pemasaran juga lebih mudah dan luas ditambah dengan adanya pedagang pengecer.

\section{Strategi S-T}

1. Bahan baku utama yaitu kedelai berkualitas tinggi namun adanya persaingan kualitas dan kuantitas tahu antar industri tahu membuat produsen harus bisa mengatasinya.

2. Harga produk tahu yang dijual terjangkau namun produsen juga harus memutar otak dengan adanya fluktuasi harga bahan baku utama yaitu kedelai.

3. Produk tahu yang diproduksi unggulan serta terjamin mutunya namun harga produk sama dari pesaing yang lebih murah bisa jadi mempengaruhi minat konsumen.

4. Memproduksi berbagai jenis tahu, yaitu tahu putih, tahu goreng, dan tahu sumendang namun adanya produk substitusi yang beragam seperti tempe juga mempengaruhi minat konsumen

\section{Strategi W-O}

1. Bahan baku kedelai di supply dari Kota Banjarmasin dengan kontinuitas bahan baku terjamin.

2. Produk tahu tidak dapat bertahan lama, namun dengan sudah banyak konsumen yang melek teknologi sehingga pemasaran dapat secara online (Via WhatsApp) dan akan mempermudah pemasaran ke konsumen.

3. Modal usaha terbatas, namun dengan adanya pedagang pengecer membantu memperluas pemasaran produk sehingga mampu mendapatkan keuntungan yang lebih besar.

4. Produk tahu tidak dapat bertahan lama namun murah dan bergizi serta sehat sehingga konsumen memilih produk tahu.

\section{Strategi S-T}

1. Bahan baku kedelai di supply dari Kota Banjarmasin, sehingga produsen harus menghindari persaingan kualitas dan kuantitas tahu antar industri tahu.

2. Produk tahu tidak dapat bertahan lama, sehingga produsen harus meningkatkan keterampilan mengenai cara membuat tahu menjadi sedikit lebih tahan lama agar menghindari konsumen membeli produk substitusi yang beragam dengan harga yang beragam pula.

\section{PENUTUP}

\section{Kesimpulan}

Berdasarkan tujuan dan hasil penelitian, maka kesimpulan dari penelitian ini adalah sebagai berikut.

1. Pola aliran rantai pasok pada industri pengolahan tahu citra puspita ada 3 yaitu pola aliran produk, pola aliran kas, dan pola aliran informasi. Untuk pola aliran produk, pola aliran kas, dan pola aliran informasi untuk bahan baku utama kedelai yaitu dari Importir Kedelai, Distributor Kedelai, terakhir ke Industri Pengolahan Tahu. Untuk pola aliran produk, pola aliran kas, dan pola aliran informasi untuk produk olahan berupa tahu yaitu dari Industri Pengolahan 
Tahu, Pedagang Besar atau Pedagang Pengecer Tahu, terakhir ke Konsumen Akhir.

2. Pihak-pihak pada rantai pasok industri pengolahan tahu Citra Puspita yaitu importir kedelai yaitu PT FKS Multi Agro Tbk, distributor kedelai yaitu Bapak Heri dari Kota Banjarmasin, industri pengolahan tahu Citra Puspita, pedagang besar tahu, pedagang pengecer tahu, dan konsumen akhir serta penyedia bahan pendukung lain seperti penyedia kayu bakar, cuka atau biang tahu, plastik untuk membungkus, minyak goreng, dan lain sebagainya.

3. Berdasarkan hasil perhitungan dari nilai skor faktor internal diperoleh hasil yaitu $2,571-0,891=1,68$. Sedangkan hasil perhitungan dari nilai skor faktor eksternal diperoleh hasil yaitu 1,793 $1,375=0,418$. Sehingga posisi industri pengolahan tahu Citra Puspita berada pada kuadran I yang berarti berada pada situasi yang menguntungkan dengan posisi strategi SO, yaitu sebagai berikut: a.) Bahan baku utama yaitu kedelai berkualitas tinggi dan kontinuitas bahan baku terjamin untuk proses produksi setiap harinya; b.) Harga produk tahu yang di jual terjangkau dan produk tahu yang unggulan serta terjamin mutunya membuat pemasaran produk menjadi lebih luas, dibantu dengan adanya pedagang pengecer; c.) Harga produk tahu yang di jual terjangkau dan produk tahu yang unggulan serta terjamin mutunya membuat pemasaran produk menjadi lebih luas dengan kemudahan pemasaran secara online (via WhatsApp); d.) Lokasi industri yang strategi mempermudah distribusi produk tahu sehingga mempermudah juga dalam pemasaran produk oleh pedagang pengecer; f.) Konsumen memilih makanan yang bergizi dan sehat namun murah, seperti contohnya tahu dengan berbagai varian seperti tahu putih, tahu sumedang, dan tahu goreng yang dapat dipilih sesuai selera konsumen; g) Lokasi industri yang strategis mempermudah distribusi dan sudah memiliki informasi mengenai permintaan dan penjualan di pasar maka pemasaran juga lebih mudah dan luas ditambah dengan adanya pedagang pengecer.

\section{Saran}

Berdasarkan kesimpulan hasil penelitian, maka saran yang diberikan yaitu sebagai berikut.

1. Untuk pemilik industri pengolahan tahu Citra Puspita, dapat memperluas lagi pemasarannya dengan memanfaatkan media promosi seperti Facebook, Instagram, dan marketplace lainnya. Hal ini bertujuan untuk mempermudah mencapai konsumen yang lebih banyak. Selain itu, perbanyakan varian tahu agar konsumen memiliki beberapa pilihan saat akan membeli. Jika memungkinkan, pemilik industri mencatat setiap penawaran dan permintaan sehingga dapat meramalkan jumlah produksi di kemudian hari untuk menyesuaikan dengan kondisi pasar. Produsen juga perlu untuk memotong mata rantai pasok seperti mengambil langsung dari Jawa atau importir langsung untuk menekan biaya produksi sehingga memaksimalkan pendapatan.

2. Untuk pemerintah, diharapkan agar lebih memperhatikan dan mendukung pelaku usaha industri pengolahan tahu, seperti menjamin kestabilan harga bahan baku kedelai. Seperti contoh membuat koperasi kedelai yang di dukung oleh pemerintah. Adanya pemasok yang di dukung oleh pemerintah juga akan mempermudah pembelian bahan baku utama, sehingga pelaku industri pengolahan tahu tidak perlu jauh-jauh membeli sampai ke luar daerah. Saran lainnya yaitu dengan memberdayakan petani kedelai di daerah Kalimantan Tengah agar kemudian hari Kalimantan Tengah bisa menjadi provinsi swasembada kedelai sehingga tidak bergantung dengan importir.

\section{DAFTAR PUSTAKA}

Peraturan Presiden Republik Indonesia No 18. 2020. Rencana Pembangunan Jangka Menengah Nasional. 
Kementrian Hukum dan Hak Asasi Manusia Republik Indonesia.

Widiantoro, Soni. 2020. Analisis Nilai

Tambah Kedelai (Glycine Max (L.)

Merrill) Menjadi Tempe (Studi Di

UMKM Milik Bapak Junaidi

Kelurahan Plaju Ulu Kecamatan

Plaju). SKRIPSI. Universitas

Tridinanti Palembang

Dinas Perindustrian dan Perdagangan

Provinsi Kalimantan Tengah. 2020.

Data Industri Pangan Per

Kabupaten/Kota di Provinsi

Kalimantan Tengah Tahun 2019.

Provinsi Kalimantan Tengah

Nazir, Moh. Ph. D. 2009. Metode

Penelitian. Ghalia Indonesia: Jakarta.

Sugiyono. (2008). Metode Penelitian Bisnis. Alfabeta: Bandung.

Zauvi. 2019. Analisis Rantai Pasok Agroindustri Tempe Di Kelurahan Gunung Sulah Kecamatan Way Halim Kota Bandar Lampung. Skripsi. Univesitas Lampung. 